\title{
Technological Development in Information Technology and the Demise of the Music Industry: The Case of Sungura Music in Zimbabwe and Digong Music of South Africa
}

\author{
Medicine Magocha
}

\author{
School of Business Leadership and College of Humanities, University of South Africa \\ Email:Medymagocha2002@yahoo.co.uk
}

Zandi Lesame

School of Business Leadership and College of Humanities, University of South Africa

Email: lesamnc@unisa.ac.za

Doi:10.5901/mjss.2014.v5n15p272

\begin{abstract}
It's agonizing to realize that someone spent months if not years of sleepless nights compiling, composing and committed to produce a piece of music art. In most cases before it gets into the market officially it is deplorable that thousands of copies would have been sold illegally and at a bargain price like R10-00 in South African currency (US\$1-00) and US\$1-00 in Zimbabwe currency. This on-the-street cheap pricing cannot remunerate the effort of the musicians neither does it benefit to the pirates. The issues of Intellectual Property Rights (IPRs) need to be respected in all forms of art. Before the 1990s, the music industry used to be lucrative for music artists but now some view it as unrewarding because fake artists copy their music (and also some films) and sell it on the streets before it reaches music stores. Copy right laws are no longer observed seriously. This paper seeks to answer the following questions: What should be done to improve music production and supply processes in Zimbabwe and South Africa? Who is to blame for this rampant music piracy in the Southern African countries - the information technologist who reproduces a music CD illegally or the musician? Management of art is complex and a number of musicians are not educated enough and thus have no basic business management knowledge and skills. This paper critiques the illegal act of music piracy in Zimbabwe and South African, and seeks to establish a music industry model of musical art marketing and sales towards profitability for music composers and producers. The article attempts to offer possible solutions to the music piracy challenge.
\end{abstract}

\section{Introduction}

Music, well before the 1980s, was considered an unseemly industry. Some considered it was an offense to be seen holding a homemade guitar and not attending school whilst others were going to school to study to become teachers, doctors and architects. It was common in Zimbabwe to hear a parent saying, "Unoda kuzoita rombe here mwanangu!" ("Do you want to be a good-for-nothing my son!"). Music and its related capabilities were not reckoned with the proper professional standing it deserved. None was valuing the intellectuality accompanied by music talent. This resulted in challenges to intellectual property rights (IPRs), copyright and patents. This challenge is reverberating in the sungura music section of Zimbabwe and digong music section of South Africa mainly concentrated in Venda District of the Limpopo Province. With the coming up of advanced musical technology the musicians took major stride into wealth and prosperity through their career, but the challenge of lack of talent recognition was not resolved. Instead piracy and violation of laws and regulations binding respect to one's piece of musical composition continued to be violated. This research seeks to find ways on which the musicians should be protected from financial losses which are resulting from IPR theft, they are being robbed of their patents and copy rights every day. Pirates are prepared to kill because they survive from being the fittest (the law of the jungle) they are not prepared to share with the legitimate owners of the product.

\section{Sungura Music in Zimbabwe}

This is the music sector in Zimbabwe which goes along with other sounds like Zimbabwe Original Rhythms of Africa (ZORA) branded by Leonard Karikoga Zhakata who had popular hits like "Mugove" (meaning my heir), Simple Music Of Kanindo Origin (SMOKO) popular brand pioneered by the late System Tazvida and his band Chazezesa Challengers, 
with popular songs like "Anodyiwa haataure" and "Tazvida irombe" (literally translated as Tazvida is a rogue), Dendera music started by the late Simon (a.k.a. Chopper) Chimbetu and is being propelled by his son Sulumani Chimbetu and the Orchestra Dendera Kings, Razor wire under the leadership of Aleck Macheso and the Orchestra Mberikwazvo. These are the most popular artists in Sungura music in Zimbabwe.

These are competing with Rhumba, Gospel, Afro-jazz, Dance hall, Chimurenga and Urban grooves. The names suggest the type of music and they also bring the nature of clients to buy.

Going back to sungura (sometimes known as museve) it can be noted that is a musical brand in Zimbabwe with a lot of sub-branches and also a lot of listenership from public organizations like political parties, galas, music concerts as well as private listenership from individuals to households. In most galas or the biras like the popularly known Muzee Bira these are popularly invited.

\section{The Aim and Objectives of the Study}

This is an exploratory and descriptive study aimed at:

- Describing and exploring the technological development in information technology and the demise of the music industry in the field of Sungura Music in Zimbabwe and Digong Music of South Africa

- In an attempt to achieve this aim, the study seeks to contribute toward the following objectives:

- To describe how the technological development in information technology is leading to the demise of music industry in Zimbabwe and South Africa;

- To explore the most common genres of music which are heavily affected by technological development information technology in Zimbabwe and South Africa;

- To expose the technological abuse in the infringement of IPRs in the Music Industry; and

- To define the possible ways of dealing with intellectual property rights in music industry of Zimbabwe and South Africa.

\section{Research Methodology}

Personal interviews and a survey of selected Zimbabweans and South Africans were conducted from July to October 2013 by the researchers. An investigation conducted by and observations by these researchers on music pirated and sold on the streets of central Pretoria, indicated that the people from across Africa sell music along Paul Kruger Street that is between Scheiding and Jacob Mare Streets. A random sample of 20 pirates was selected for interviews and the interviews were consequently conducted over three consecutive days in July 2013. For the survey research conducted between July and October 2013, 50 randomly selected people were asked about the music they enjoy listening to on their leisure time. The results of this research are stated in Section 5 (the next section) of this article. Triangulation was therefore executed to collect data. Triangulation is often used to indicate that more than one method is used in a study with a view to double (or triple) checking results. Neuman (2000) defines triangulation as the use of both qualitative and quantitative research methods to "better look at something from several angles than to look at it in only one way" or that it is "cross examination". In this study, triangulation was employed to ask respondents what types of music they listen and also to investigate why piracy happens. Qualitative research means that the raw data exist in a non-numerical form (e.g., reports and conversations) (Rosnow and Rosenthal, 1996). Conversations were used in the interviews as data collection techniques. Quantitative means that the raw data exist in a numerical form (e.g., observers' ratings and percentages). In this study, figures and percentages, as well as tables are employed to present gathered and analyzed data). Additionally, other qualitative data gathered with the personal interviews is recorded in this chapter under themes; thematic analysis was employed to arrange the data, some of which are presented as sub-headings of Section 5.

Triangulation was, therefore, employed in a study to increase the reliability of the study's results and it was employed for that reason in this research as well. Triangulation is based on the idea that one can be more confident with a study's result if different methods lead to the same result or almost similar results. Each research method (i.e., the survey and the interview) has its strengths and weaknesses, so by employing triangulation the researcher adds value to one's research as the strengths of one research methods may support the weaknesses of another research method (Babbie, 2001). The researchers expected that triangulation could add that valuable information to this study by employing the two research methods. One type of triangulation were employed in this study, "methods triangulation" (Neuman, 2000). With regards to the triangulation of methods, the survey questionnaire was the quantitative method used and the personal interviews were employed for collecting qualitative data. 


\section{Presentation and Discussion of the Research Findings}

The survey results indicated that the respondents listened to at least seven types of music which are indicated in Figure 1.

Figure 1: Types of music preferred or listened to the respondents

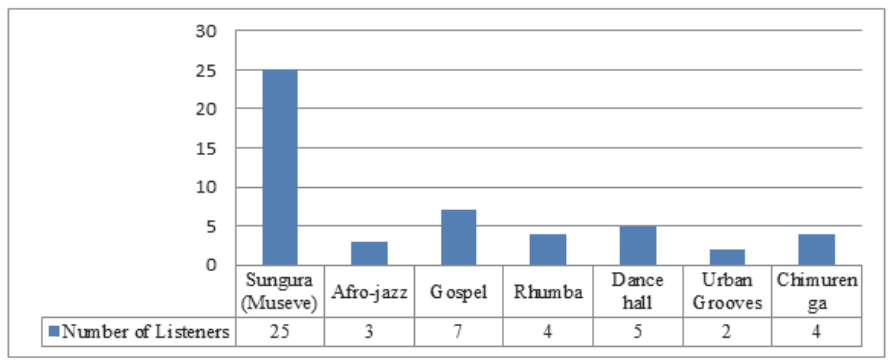

Figure 1 indicates that twenty-five ( 25 persons or 50 per cent) of the Zimbabwean respondents reflected that they enjoyed listening to sungura (museve) music which is $50 \%$ of the population, seven (7) persons said they preferred gospel which is $14 \%$ of the population, five (5) respondents constituting $10 \%$ of the survey population said they enjoy dance hall music, four (4) individuals stated that they enjoyed chimurenga music and the other four (4) enjoyed rhumba, three (3) of them enjoyed Afro-jazz and two (2) listened more to urban grooves.

With reference to the South African respondents, upon being surveyed, three persons stated that they enjoyed digong music were those fans who had developed interest in the music of music artists such as the late Tenet's Shangaan disco and musician known as Penny Penny's songs like "Yogo Yogo". The research forecasted that in those areas where digong is popular sungura music is also popular though the sungura is being played by Zozo and the sungura is of South African Venda version. It is highly characterized by Zimbabwe sungura string guitar component. Music like any oral literature it borrows some art forms from neighbouring states and from within other local art aesthetics.

\subsection{Access to Music of Listener's Choice: Casting doubt on the Dilemma between Buying or Manipulating Technology towards a free Bargain or "free" listening}

There are a number of ways in which music can be accessed from the music producer to the final music end-user who is the listener. A long time ago music used to be packaged on the records which were played by gramophones; from there radio cassettes were invented and from cassettes compact discs were designed of late music is played on computers via the USBs and online. All these inventions are arising due to technological advancement. The question is, are these technological advancements advancing the life styles of the musicians who are at the bottom of this production chain? Is there systematic relationship between technology producer and the music composer? Who is enjoying the spoils? The answer is not obvious. Looking at the Table 1 below it can be noted that music can be acquired in various ways and all of them should promote business thereby making the music world viable. However there are some ways which are damaging to the music industry.

Table 1: Ways of accessing music from the producers

\begin{tabular}{|l|l|}
\hline Type of Music & Ways of getting the Music \\
\hline Sungura (Museve) & Buying, downloading, YouTube, shows \\
\hline Afro-jazz & Downloading \\
\hline Gospel & Recording for the Church \\
\hline Rhumba & Gifts from Democratic Republic of Congo (DRC) Friends \\
\hline Dance hall & Attending Shows \\
\hline Urban Grooves & Attending Shows \\
\hline Chimurenga & Cassettes and Computer Discs (CDs) Recorded \\
\hline
\end{tabular}




\subsection{Methods and Technological ways of tapping into the musician's Talent}

The research conducted in Zimbabwe at Mbare and in South Africa at Musina reflected that when it comes to sungura (museve) music 10\% of the funs acquire it through downloading from the technological devices, $14 \%$ bought and they mentioned they could buy from original dealers or from the street music pirate dealers. There were none of the funs who could get sungura music by recording from the church. Eight (8)\% received it as gifts, $12 \%$ accessed it from shows. On the issue of shows one musician stated, "Most of the songs sold by these guma-gumas referring to music pirates are usually recorded by very powerful machines during the shows and the produced illegally from the house to the street". Two (2)\% got it from YouTube and four (4)\% from recording from other people's original discs to the MP3 blank ones which they bought at a price of R10 (or one US dollar - US\$1) for 20 discs in some South African shops.

Figure 2: Percentage access of music through different means of capturing

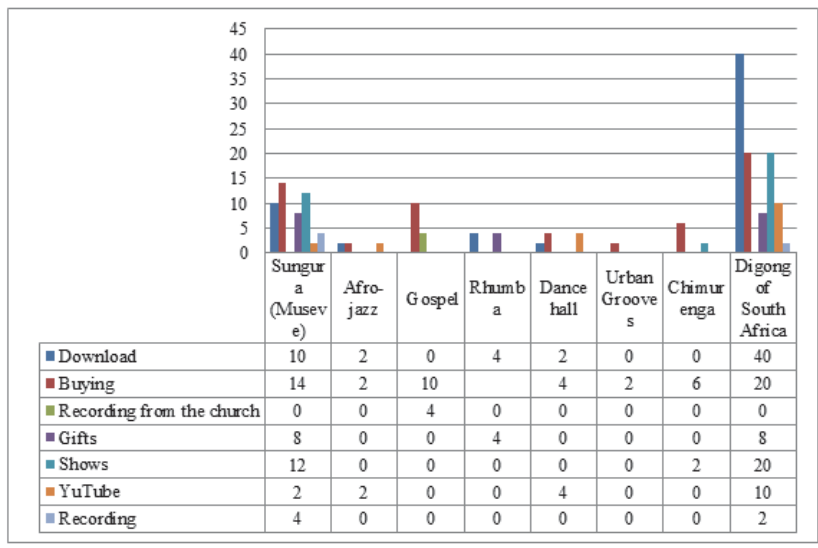

According to the conducted research digong music of South Africa proved to be highly affected by technological advancement to an extent that it is falling. The results of the research came as follows $40 \%$ of the music was accessed through downloading from online sources, $20 \%$ was bought from both original dealers and music pirates, eight (8)\% was from gifts, 20\% from shows, 10\% from YouTube, two (2)\% from recording. The results were catastrophic more money which was supposed to be rewarding the musicians in that music genre are leaking because of uncontrolled technology.

5.3 Technological advancement and Piracy the situation of Zimbabwe Sungura Museve Music at Bosman street and surrounding areas in Pretoria

Most of the highly pirated music genre in Pretoria Bosman is sungura music of Zimbabwe. The interviews yielded the following results - as can be seen in Figure 3.

Figure 3: Popular music genres sold by pirates in Pretoria Bosman Street and Area

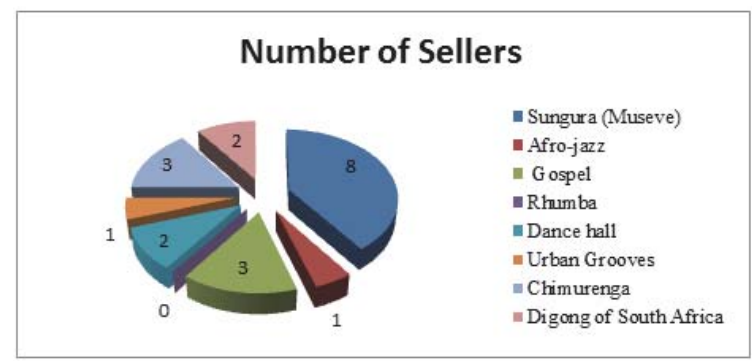


Zimbabwean Sungura (museve) music dominated with $40 \%$ of the overall sales on the pirate market (the music black market). This situation is unacceptable and unethical for the music artist loses income when one's CD is copied by Zimbabwean pirates and sold on the streets of. The least pirated music type was urban grooves. According to the research urban grooves was not pirated more because it is not popular with the Zimbabwean migrants in South Africa. Digong of South Africa had a piracy rate of two (2)\%, rhumba had a piracy rate of zero (0)\% the reasons why it had a zero $(0) \%$ were not established. Generally speaking, five categories of works, performances or productions are the most exposed victims of piracy, namely:

- sound recordings;

- video recordings;

- computer programs;

- broadcasts; and

- books.

Sungura (museve) and digong music suffer a lot of piracy because they are melodious to a number of people and besides that, people are not worried about the meaning but they like the tunes and enjoy dancing associated with this type of music (the chibhasikiro dance, museve dance and the borrowdale dance)

\subsection{Technological abuse in the infringement of IPRs in the Music Industry}

Computers, smart-phones and the internet are now linked to almost every part of our daily lives. This creates new vulnerabilities that organized crime groups are quick to exploit. Criminals are using this technology to conduct new crimes and to commit traditional crimes in new ways and on cyberspace. They can commit these crimes with access to countless victims, with anonymity and from anywhere in the world, making them difficult to detect and pursue. Whilst technology especially, information and communication technology development is a blessing to a number of industries, the research is convinced that to music industry it is an equation which need to be balanced. How is the question of the hen and the egg? More and more users are accessing the internet through an ever-changing array of mobile devices-tablets, smartphones and internet TV—providing new and increased opportunities for cyber criminals. According to the 2010 McAfee Threats Report, mobile phone security threats rose by 46 per cent from 2009 to 2010.

The notion of piracy covers a number of different phenomena. For example, in the field of music, three expressions are used in common parlance which is all covered by the wider notion of piracy as used here. Those expressions are "counterfeits," "bootlegs" and "pirate copies." "Counterfeits" are usually exact copies of a sound or video disc or tape with, for instance, exactly the same packaging as the original, usually including even the trademark. The copies could be either tapes or - more sophisticated - industrially manufactured CDs. "Bootlegs" are copies of recordings of a live performance or a broadcast, if the recording was made without the authorization of the right-owner concerned. "Pirate copies," finally, are unauthorized copies of a sound or video recording which do not attempt to imitate the original but are generally of low quality, with handwritten labels, etc. Those are becoming rarer because in general people prefer recordings of higher quality. The use of the notion "piracy" in the following covers all three kinds of infringements now mentioned (Choo, 2008).

The common cybercrimes that lead to this include hacking and phishing.

In the computer security context, a hacker is someone who seeks and exploits weaknesses in a computer system or computer network. Hackers may be motivated by a multitude of reasons, such as profit, protest, or challenge (Bruce, 1993). The subculture that has evolved around hackers is often referred to as the computer underground and is now a known community (Blomquist, 1999). The hackers usually manipulate the weaknesses in the musician's computer systems to steal what he/she would have prepared for the audience in present or for the future. While other uses of the word hacker exist they are not related to computer security, but they refer to someone possessing an advanced understanding of computers and computer networks. Hackers can do anything for example; hackers have taken revenge on the music industry after Romania's first convicted file-sharer was given a heavy fine. The industry said they had selected the individual at random, but hackers responded rather less randomly by causing the music industry website to block as malicious by both Google and Firefox (Torrent Freak, 2009). From this people will see how vicious hackers are and one can only be a hacker through the use of advanced technologies. This does not happen to Romania alone but in Zimbabwe of late this has been a common issue where musicians would be hacked and their music would be food selling on South African streets in Pretoria and Johannesburg before it is even produced in the country.

Phishing is the act of attempting to acquire information such as usernames, passwords, and credit card details (and sometimes, indirectly, money) by masquerading as a trustworthy entity in an electronic communication (Ramzan, 
2010; Van der Merwe et al, 2005).Communications purporting to be from popular social web sites, auction sites, banks, online payment processors or IT administrators are commonly used to lure the unsuspecting public. Phishing emails may contain links to websites that are infected with malware. Phishing is typically carried out by email spoofing or instant messaging and it often directs users to enter details at a fake website whose look and feel are almost identical to the legitimate one. Phishing is an example of social engineering techniques used to deceive users, and exploits the poor usability of current web security technologies. Attempts to deal with the growing number of reported phishing incidents include legislation, user training, public awareness, and technical security measures.

Phishing attacks are commonly reported in the technology world - when impostors try to scam people out of money by tricking them into handing over their personal details. But now it's said the technique has found its way into pop music. Producer Richard X says he's received contact from fraudsters "disguising" themselves as industry workers requesting he sends them music. "They get a little bit of information by searching databases, publisher catalogues or reading forums," stated Richard X (Cochrane, 2012).

Numbers of musicians are not aware of these things mainly because of their uneducated status and background; as far as sungura museve and digong music is concerned most musicians confirmed that they have never attended school for music. Therefore it would be a gross error of statistics type II to over generalise their knowledge and understanding of developments in information and communication technologies.

\subsection{The Impact of Cybercrimes on the Music Industry}

With effect to the selected music categories it was acknowledged that cybercrimes results to a number a losses and disturbances to the business and music industry communities. These include:

- loss of online business and consumer confidence in the digital economy;

- the potential for critical infrastructure to be compromised affecting water supply, health services, national communications, energy distribution, financial services and transport;

- $\quad$ loss of personal financial resources and the subsequent emotional damage;

- loss of business assets;

- costs to government agencies and businesses in re-establishing credit histories, accounts and identities;

- costs to businesses in improving cyber security measures;

- fuelling other criminal activity; and

- costs in time and resources for law enforcement agencies.

According to PricewaterhouseCoopers' Global Economic Crime Survey released in March 2012, 30 per cent of businesses surveyed in Australia reported a cybercrime incident-including malicious software attacks, tampering of hardware, leaking of confidential data, hacking and attacks on websites-over the past year (Battersby, 2012).Of those, 16 per cent had lost more than $\$ 5$ million and half had lost more than $\$ 100000$ (CERT, 2013). The situation is not in Australia alone but across the world, so this is an alert to the people in Africa especially those in music industry with particular reference to sungura museve of Zimbabwe and digong of South Africa.

\subsection{Principles to help the Societies Understand the Musician's Plight during the so Called Technological Advancement Era}

Technology as realized from the findings one can justifiably say the impact need to be regulated so that it can reach certain levels of tolerance acceptable to the musician and the technology producer. All are consumers in one way or the other. Hence whatever they are doing is a source of living but in all fairness no system should jeopardize the other.

Four key principles informing the national approach to cybercrimes related to music industry:

\subsubsection{Understanding the problem.}

A better understanding of the cybercrime threat will ensure better policy and law enforcement responses, and enable music businesses and individuals to take targeted measures to protect themselves.

\subsubsection{Partnerships and shared responsibility.}

Governments cannot act alone in combating cybercrime. Tackling this threat is, and always will be, a shared 
responsibility between music industry, technology industry, individuals and governments. This means forging mutually beneficial partnerships to share information and combine efforts to combat cybercrime.

\subsubsection{Focusing on prevention.}

In most cases, measures to prevent cybercrime are low cost, easily implemented and very effective. Users need to take steps to avoid falling victim to cybercrime and governments and industry need to be proactive in anticipating where new threats might emerge.

\subsubsection{Balancing security, freedom and privacy.}

The internet is built upon the freedom, creativity and innovation of users. In striving to create a more secure online environment and take action against cyber criminals, our response must balance the rights of music fans, musicians and technology producers to freely roam, create and interact on the internet, and uphold individuals' right to privacy.

\subsection{Protecting Intellectual Property Rights (IPRs) in the Music Industry}

Music industry is one of the largest globally therefore; intellectual property rights are an important foundation of the industry, providing creators and innovators with necessary benefits of their creativity. These rights come in various legal forms, such as copyrights, trademarks, patents, trade secrets and other inherent authorship rights recognized in many countries. The National Association of Music Merchants (NAMM), urges its members to develop protection and enforcement programs for their creative endeavors in consultation with an attorney experienced in the field of intellectual property rights.

The NAMM is committed to the principle that intellectual property rights are to be respected, and that the use of intellectual property rights without the consent of the owner or otherwise pursuant to law violates rights of authors, inventors, and corporations. Copyright, trademarks, patents, and other forms of intellectual property are protected by state and federal laws in the United States and by the laws of other countries (http://www.namm.org/policies/namm-andintellectual-property-rights).

The research established from a discussion that a number of musicians cannot be protected because they do not know anything in line with the IPRs. A large number of musicians believe that music is not theirs but it's a community asset. During interviews musicians could not claim the ownership of their songs. Some could be heard saying composition of a song comes as an inspiration from the musician's ancestors. This allegation or mentality exposes them to the society music mongers. Yet, the NAMM, believe that inventors, manufacturers, publishers, and other creators and owners of intellectual property are entitled to protect their rights in accordance with the law.

The following suggestions were given on how to protect the loss of benefits from the music industry;

(i) Musicians should work closely with the technology producers

(ii) Musicians should not undermine themselves

(iii) Corporate social responsibility should increase within the music industry

(iv) Musicians should be united and support their industry and trade

(v) The consumer councils should see music as part of the intangible heritages which deserves to be guarded jealously.

(vi) The state politics and economics should see music as a source of revenue for both the musician and the country.

(vii) Those people who are caught practicing piracy should be employed to controlled the systems

(viii) The powerful recording machines should be purchased by those with licences to operate in the industry.

Those suggestions mentioned above are some of the ways music can be protected from total demise which is resulting from technological advancements.

In addition to that, it is the responsibility of the creators or owners of intellectual property rights (the musicians and related parties) to take the necessary actions to ensure protection of their rights consistent with their business goals. The NAMM encourages intellectual property owners to develop a protection program, which might involve filing applications with requisite governmental bodies in their countries. In some instances (for example, situations involving counterfeiting or infringement), the filing of such applications can be a prerequisite to enforcing intellectual property rights. For example, to protect a brand, registering a trademark can be helpful, or in some countries necessary. As another example, procuring a patent on an invention is necessary in order to combat copying of the invention. The NAMM does not provide 
intellectual property protection or planning services, nor do mediation on disputes among members as a neutral trade group, but can provide members with resources that may assist in protecting IP rights.

Challice (2009) asserts that all intellectual property systems need to be underpinned by a strong judicial system for dealing with both civil and criminal offenses, staffed by an adequate number of judges with suitable background and experience. Intellectual property disputes are in the main matters to be decided under civil law and the judicial system should make every effort to deal with them not only fairly but also expeditiously. Without a proper system for both enforcing rights and also enabling the grant of rights to others to be resisted, an intellectual property system will have no value.

The measures should include the following:

- $\quad$ seizure of the goods suspected to be unauthorized copies;

- sealing the premises where the unauthorized copies are being manufactured, packaged, stored or offered for sale, rental, lending or other distribution;

- seizure of the tools that could be used to manufacture or package the unauthorized

copies, and of business documents referring to the copies;

- ordering the termination of the manufacture or distribution of the unauthorized copies; and

- ordering the disclosure of the source of the copies suspected to be unauthorized copies.

Because of the recognized need to take efficient action against copyright piracy, some countries have set up special enforcement units either in the ministry responsible for copyright law matters or within the police or customs forces. Zimbabwe and South Africa should do the same. Also, in some countries, special State bodies, have particular responsibilities in the field of enforcement. They can act on behalf of their members, initiate investigations and bring matters to court. In most countries however the enforcement is entrusted to the ordinary enforcement authorities, that is, the courts, the police, the public prosecutors and the customs authorities.

\section{Conclusion}

The research exposed a number of issues pertaining to the developments in information and communication technologies establishing the impact and effects of these developments which are leading to the downfall of the music fraternity. The research randomly selected the two major music genres. One from South Africa, and the other from Zimbabwe. That is, digong and sungura museve music genres respectively. The major objective of this paper was to expose the irregularities in technology industry which are affecting the music industry drastically. There are some technologies which are a merit to an organization and there are some which are a drawback. Music industry is facing a hard time on its sales because piracy is doing an anticompetitive thing when it comes to pricing. A normal original compact disc with six (6) tracks is going for R150 to R200 in music dealer shops but a copied MP3 with more than 30 to 40 tracks is going for R10. This act is counterproductive because it destroys music creativity, innovation and industriousness of the musicians. It is therefore the appeal and recommendation of this paper that the governments should try their level best to control the rights and the freedom packs of these endangered intangible heritages. Before there was an industry or an association, there was a belief in music. That belief led to a vision: Which envisioned a world in which the joy of making music is a precious element of daily living for everyone; a world in which every child has a deep desire to learn music and a recognized right to be taught; and in which every adult is a passionate champion and defender of the right. That vision led to a mission: To strengthen the music products industry and promote the pleasures and benefits of making music. More than a century later, that vision and mission have attracted a growing, thriving worldwide community of thousands of deeply passionate, talented companies that make, buy and sell the instruments that allow millions of people to make music. That community is called the NAMM, the trade association of the international music products industry. However the NAMM is failing to control the problems caused by the dynamics of vicious cyber world.

\section{References}

Australia Cyber Crime and Security Survey Report (CERT). (2013).

Retrieved from: https://www.cert.gov.a Retrieved on 28/09/2013

Babbie, E. (2001). The Practice of Social Research. Belmont, California: Wadsworth Thomson Learning. 9th Edition.

Battersby, L. (2012). 'Business facing war against cybercrime'. Sydney Morning Herald March, 1. Retrieved from: http://www.smh.com.au/business/business-facing-war-against-cybercrime-20120229-1u3av.html Retrieved on
25/09/2013

Blomquist, B. (1999). "FBI's Web Site Socked as Hackers Target Feds". New York: New York Post. 
Challice, G. (2009). The Australian Institute of Criminology Technical and Background Paper No. 32.

Choo, K. K. R. \& Smith, R. G. (2008). 'Criminal exploitation of online systems by organized crime groups'. Asian Journal of Criminology 3(1): 37-59

Cochrane, G. (2012). Fraudsters go phishing for pop music, says producer. BBC Radio 1 Newsbeat. Retrieved online at: http://www.bbc.co.uk/newsbeat/16785833.

Retrieved on 03/10/2013 and http://www.smh.com.au/digital-life/mobiles/mobile-phone-security-threats-rise-sharply-mcafee-20110209lam48.html

Retrieved on 07/10/2013 National Association of Music Merchants (NAMM). (2012). The National Association of Music Merchants_News. http://www.namm.org Retrieved on 21/06/2012

Neuman, W. L. (2000). Social Research Methods: Qualitative and Quantitative Approaches. Boston: Allyn \& Bacon. $4^{\text {th }}$ Edition.

Ramzan, Z. (2010). "Phishing attacks and countermeasures". In Stamp, Mark \& Stavroulakis, Peter. Handbook of Information and Communication Security. London: Springer.

Rosnow, R. L. \& Rosenthal, R. (1996). Beginning Behavioural Research: A Conceptual Primer. Englewood Cliffs, New Jersey: PrenticeHall, Inc.

Sterling, B. (1993). "Part 2 (d)". The Hacker Crackdown. McLean, Virginia: Indy Publishers.

Torrenttreak. (2009). Hackers Whack Music Industry For Punishing Pirate. Retrieved online at: http://torrentfreak.com/hackers-whackmusic-industry-for-punishing-pirate-090802/ Retrieved on 01/10/2013

Van der Merwe, A. J, Loock, M, Dabrowski, M. (2005). Characteristics and Responsibilities involved in a Phishing Attack. Cape Town: Winter International Symposium on Information and Communication Technologies. 